\title{
Phylogenetic placement of enigmatic percomorph families (Teleostei: Percomorphaceae)
}

AUTHORS: Millicent D. Sanciangco ${ }^{1}$, Kent E. Carpenter ${ }^{1} \&$ Ricardo Betancur-R. ${ }^{2}$

${ }^{1}$ Department of Biology, Old Dominion University, Norfolk, VA, USA, 23529

${ }^{2}$ Department of Biology, University of Puerto Rico - Río Piedras, P.O. Box 23360, San Juan, Puerto Rico, 00931

Corresponding author: Ricardo Betancur-R., Department of Biology, University of Puerto Rico Río Piedras, P.O. Box 23360, San Juan, Puerto Rico, 00931. E-mail: betanri@ fishphylogeny.org. 


\begin{abstract}
Percomorphs are a large and diverse group of spiny-finned fishes that have come to be known as the "bush at the top" due to their persistent lack of phylogenetic resolution. Recently, the broader Euteleost Tree of Life Project (EToL) inferred a well-supported phylogenetic hypothesis that groups the diversity of percomorphs into nine well-supported series (supraordinal groups):

Ophidiaria, Batrachoidaria, Gobiaria, Syngnatharia, Pelagiaria, Anabantaria, Carangaria, Ovalentaria, and Eupercaria. The EToL also provided, for the first time, a monophyletic definition of Perciformes - the largest order of vertebrates. Despite significant progress made in accommodating the diversity of percomorph taxa into major clades, some 62 families (most previously placed in "Perciformes", as traditionally defined) were not examined by the EToL. Here, we provide evidence for the phylogenetic affinities of 10 of those 62 families, seven of which have largely remained enigmatic. This expanded taxonomic sampling also provides further support for the nine EToL supraordinal series. We examined sequences from 21 genes previously used by the EToL and added two fast-evolving mitochondrial markers in an attempt to increase resolution within the rapid percomorph radiations. We restricted the taxonomic sampling to 1229 percomorph species, including expanded sampling from recent studies. Results of maximum likelihood analysis revealed that bathyclupeids (Bathyclupeidae), galjoen fishes (Dichistiidae), kelpfishes (Chironemidae), marblefishes (Aplodactylidae), trumpeters (Latridae), barbeled grunters (Hapalogenyidae), slopefishes (Symphysanodontidae), and picarel porgies (formerly Centracanthidae) are members of the series Eupercaria ("new bush at the top"). The picarel porgies and porgies (Sparidae) are now placed in the same family (Sparidae). Our analyses suggest a close affinity between the orders Spariformes (including Lethrinidae,
\end{abstract}


Nemipteridae and Sparidae) and Lobotiformes (including the tripletails or Lobotidae, the barbeled grunters, and tigerperches or Datnioididae), albeit support for this group is low. None of the newly examined families belong in the order Perciformes, as recently defined. Finally, we confirm results from other recent studies that place the Australasian salmons (Arripidae) within Pelagiaria, and the false trevallies (Lactariidae) close to flatfishes, jacks, and trevallies, within Carangaria.

\section{Keywords}

Ichthyology, phylogenetic placement, percomorph systematics, multi-locus data, classification. 


\section{Introduction}

Percomorph fishes (Subdivision Percomorphaceae) are one of the nine major radiations of jawed vertebrates (Alfaro et al., 2009), including around 55\% (>17,000 species) of extant teleost diversity (Betancur-R. et al., 2013a; Friedman, 2010; Johnson, 1993; Near et al., 2013; Nelson, 1989b; Nelson, 2006). Percomorphs have come to be known as the "bush at the top" (Nelson, 1989a) of the fish tree of life due to their historical lack of phylogenetic resolution. The Perciformes (perches) is the most species-rich order of percomorphs and the largest order of vertebrates. For a long time, the Perciformes has been regarded as a non-monophyletic “wastebasket" (Nelson, 2006; Wiley and Johnson, 2010), and at least 160 families and 20 suborders, with dubious phylogenetic integrity, have been placed within the order (Johnson, 1984; Nelson, 2006; Wiley and Johnson, 2010). Several studies using morphological and molecular data have recovered the Perciformes as either a para- or polyphyletic group (Chen et al., 2003; Dettai and Lecointre, 2005; Johnson and Patterson, 1993; Lauder and Liem, 1983; Lautredou et al., 2013; Li et al., 2009; Li et al., 2008; Mahon, 2007; Miya et al., 2003; Nelson, 2006; Smith and Craig, 2007; Wiley and Johnson, 2010). Johnson and Patterson (1993) considered that Perciformes may be monophyletic but only if its taxonomic limits are expanded to include members of the Scorpaeniformes (mail-cheeked fishes), Pleuronectiformes (flatfishes), and Tetraodontiformes (plectognaths). Springer and Johnson (2004) suggested that the plectognaths (including Caproidei) are "pre-perciforms" lineages, whereas Nelson (2006) noted that flatfishes and plectognaths are probably perciform derivatives. Li et al. (2008) and Li et al. (2009) recovered a polyphyletic Perciformes, in which traditionally-assigned perciform taxa are placed close to the Lophiiformes (anglerfishes), Gasterosteiformes (sticklebacks), 
Scorpaeniformes, and Mugiliformes (mullets). Wiley and Johnson (2010) also noted the nonmonophyly of "Perciformes", but erected monophyletic orders (based on morphology) for many of the suborders formerly included within the Perciformes sensu lato. These authors also placed the diversity of percomorphs, comprised by Pleuronectiformes, Tetraodontiformes, Lophiiformes, Batrachoidiformes (toadfishes), and Ophidiiformes (cusk-eels), in the division Percomorphacea (formerly Percomorpha). Wiley and Johnson (2010) proposed that Perciformes sensu stricto should only include the groups (formerly) placed in the suborder Percoidei (sensu Nelson 2006), but provided no evidence for its monophyly.

Percoidei (sensu Nelson 2006), the largest perciform suborder, has also been notorious by its lack of synapomorphies and resolution among higher-level percomorphs (Johnson, 1984; Nelson, 2006). Regan (1913) defined Percoidei by the absence of special peculiarities that characterize other perciform suborders. Johnson (1984) identified two artificial groupings for percoids: the "basal", or more generalized percoids, and the remaining percoids characterized by modifications of the cranial bones in addition to opercular and pectoral series spination. His more generalized percoids include Acropomatidae (lanternbellies), Gerreidae (mojarras), Girellidae (nibblers), Haemulidae (grunts), Kyphosidae (sea chubs), Sciaenidae (drums and croakers), Scorpididae (halfmoons), Sparidae (porgies), and Terapontidae (tigerperches), a group that he also considered to be "more primitive" among a large subgroup of percoid families.

Smith and Craig (2007), based on combined mitochondrial and nuclear sequences (4036 bp) from 180 percomorph taxa, noted that there is no phylogenetic distinction between Perciformes, Percoidei, and Percomorpha because "percoids" are spread throughout the Percomorpha (sensu Johnson and Patterson 1993). According to Smith and Craig, members of the Percoidei are placed among lineages of Perciformes, Pleuronectiformes, and 
Tetraodontiformes, including representatives of Atherinomorpha, Gasterosteiformes, and Scorpaeniformes (Smith and Craig, 2007). Dettai and Lecointre (2005) and Li et al. (2009) also obtained percoids in multiple clades together with members of scorpaenids, trachinoids, and ophidiiforms, and emphasized the need for a broad-scale taxonomic sampling to resolve percoids, especially for members of dubious morphological affinity. Smith and Craig (2007) proposed a revision for Nelson's (2006) percoid taxonomy by removing Percidae from Percoidei and Trachinidae from Trachinoidei, and by creating a new non-monophyletic suborder (wastebasket), the Moronoidei.

More recently, a broad-scale phylogenetic study of bony fishes by the Euteleost Tree of Life (EToL) project examined 21 genetic markers and 1410 taxa in 369 families (Betancur-R. et al., 2013a). This study proposed a phylogenetic classification of fishes based on molecular data, erecting nine well-supported series under the subdivision Percomorphaceae (Betancur-R. et al., 2013a; Betancur-R. et al., 2014) (Fig. 1). These series include the cusk eels (Ophidiaria, with one order); toadfishes (Batrachoidaria, with one order); kurtids, apogonids, and gobioids (Gobiaria, with two orders); seahorses, pipefishes, gurnards, goatfishes and allies (Syngnatharia, with one order); tunas, mackerels, butterfishes, and allies (Pelagiaria, with one order); armored sticklebacks, gouramies, and snakeheads (Anabantaria, with two orders); billfishes, threadfins, jacks, snooks, flatfishes, and allies (Carangaria, with at least three orders); cichlids, blennies, needlefishes, killifishes, silversides, mullets, and allies (Ovalentaria, with at least seven orders); and the new "bush at the top," the Eupercaria (with at least 13 orders including Perciformes). The new circumscription of Perciformes is now monophyletic, comprising around 60 families. This delimitation of the order is substantially smaller compared to Nelson's inclusion of 160 families (Betancur-R. et al., 2014). Previous molecular studies have also examined members of 
these major clades, in combination with other representatives using different sets of markers (Arcila et al., 2015; Betancur-R et al., 2013b; Betancur-R. and Orti, 2014; Campbell et al., 2013; Chen et al., 2003; Dettai et al., 2004; Dettai and Lecointre, 2005; Kawahara et al., 2008; Li et al., 2009; Li et al., 2011; Miya et al., 2013; Miya et al., 2001; Miya et al., 2005; Miya et al., 2003;

Near et al., 2012a; Near et al., 2012b; Thacker, 2009; Wainwright et al., 2012). The EToL study also presented a revised time-scale of bony fish evolution based on 60 calibration points, with all major lineages in Percormorphaceae originating between $132 \mathrm{Ma}$ and $82 \mathrm{Ma}$, before the end of the Cretaceous.

Despite significant progress made in accommodating the diversity of percomorph taxa into major clades, phylogenetic resolution within the newly discovered groups is weak and at least five of these are rapid radiations characterized by short basal internodes, requiring additional study. More recently, Near et al. (2013) estimated a phylogeny of 579 (mostly acanthomorph) taxa based on a subset of the EToL markers. Their results are largely congruent with those obtained by Betancur-R. et al. (2013a), although Near et al. (2013) chose to delimit 14 percomorph clades instead of nine. These authors examined 25 families not included in the global EToL phylogeny, many with enigmatic phylogenetic placement (e.g., Callanthiidae and Cepolidae). Finally, Betancur-R. et al. (2015) had recently inferred a global phylogeny of rayfinned fishes by combining data from the two large-scale studies that used EToL markers (Betancur-R et al., 2013a; Near et al., 2013), providing the most comprehensive taxonomic coverage for fishes to date. Problems still exist, however, regarding the classification of 102 families (62 in Percomorphaceae) not included in these studies and those with uncertain placement in the global fish tree.

The main goals of this study are to further test the EToL Percomorphaceae series with 
expanded taxonomic sampling and to investigate the position of seven families that, to the best of our knowledge, have not yet been included in broad-scale phylogenetic assessments of the percomorphs. These comprise the marblefishes (Aplodactylidae), bathyclupeids (Bathyclupeidae), picarel porgies (Centracanthidae), kelpfishes (Chironemidae), barbled grunters (Hapalogenyidae), trumpeters (Latridae), and slopefishes (Symphysanodontidae). We also augment the familial, generic and species diversity of the global percomorph phylogeny by adding taxa previously not examined by the large-scale phylogenetic studies. These include three families (Lactariidae, Arripidae, and Dichistiidae) that were examined by other studies, albeit with a much smaller taxonomic representation. Finally, in addition to the EToL markers previously examined, we include sequences from two other fast-evolving mitochondrial genes, COI (cytochrome oxidase I) and Cyt $b$ (cytochrome $b$ ).

\section{Materials and Methods}

We constrained our taxonomic sampling to include only percomorph taxa from the most recent global fish dataset (Betancur-R. et al., 2015) and examined 49 additional species (51 individuals as operational taxonomic units [OTUs]) for a total of 1229 unique species (1231 OTUs; Table S1). For the additional species, we used fresh samples collected from expeditions, purchased from fish markets, or obtained from the Ichthyology Collection at University of Kansas and other museums. We included all the percomorph sequences from the 21-gene dataset and added two fast-evolving mtDNA genes, cytochrome oxidase I (COI, 815 sequences) and cytochrome $b$ (cyt $b, 388$ sequences), for a total of 1203 additional mtDNA sequences. These mtDNA sequences were newly generated for this study, obtained from our previous studies (Sanciangco et al., 2011), or retrieved from the NCBI database. DNA isolation, amplification via nested PCR, 
sequencing, sequence alignment, and phylogenetic analyses followed previous studies (BetancurR et al., 2013a; Sanciangco et al., 2011). We used SequenceMatrix v1.7.8 (Vaidya et al., 2011) and Geneious (Biomatters Ltd.) to concatenate individual gene sequences. The final dataset is a concatenation of 1231 OTUs, each including three genes or more, plus Symphysanodon, which only had two genes sequenced. The dataset has eight partitions, including three codon positions across all nuclear exons, three codon positions across all mtDNA protein-coding genes, plus the mtDNA 16S and the nuclear hoxc6a. We analyzed the concatenated dataset using maximum likelihood (ML) in RAxML v7.2 (Stamatakis, 2006) by selecting the best tree inferred from 10 independent replicates ran under the GTRGAMMA model. We assessed branch support using 1000 replicates obtained using RAxML's rapid bootstrapping algorithm, with the collection of sample trees used to draw the bipartition frequencies (bootstrap support or BS) on the optimal tree. We performed all RAxML analyses using the CIPRES portal v3.1.

To overcome the computational burden of analysing large phylogenetic datasets in a Bayesian framework, we time-calibrated the resulting RAxML tree under penalized likelihood in treePL (Smith and O'Meara, 2012) using a set of 57 secondary calibrations in Percomorphaceae. These secondary calibrations (fixed mean nodal ages) were obtained from a Bayesian analysis of a subset of 201 taxa with 61 fossil age constraints (primary calibrations) using node-dating approaches. Further details on alignment, concatenation, ML inference, fossil calibrations, and divergence time estimates are given in the original study (Betancur-R. et al., 2013a).

\section{Results and Discussion}

Our final dataset is a concatenated alignment of 23 genes and is $44.70 \%$ complete for 1231 OTUs, including an outgroup (Hoplostethus occidentalis/H. atlanticus, Family Trachichthyidae, 
Order Beryciformes). Symphysanodon typus was the only species included in the analysis that had only two genes sequenced. This is the first time a representative of the family Symphysanodontidae (slopefishes) is examined in a molecular phylogenetic analysis of percormorphs. The alignment file and the time-calibrated RAxML tree are available as supplementary material. All new sequences are also available from GenBank (Table S1).

The results of our RAxML analysis (Fig. 1) recovered consistent placement for all major percomorph series (Fig. 1) with similar clade components that are largely concordant with those obtained by other recent phylogenetic studies of fishes (Betancur-R et al., 2013a; Betancur-R. et al., 2015; Near et al., 2013). The complete phylogenetic tree is shown in Figure S1. Figures 2 to 6 provide higher-resolution within selected percomorph clades, emphasizing the target groups (new additions). We follow the phylogenetic classification of Betancur-R. et al. (2014) and present the findings in phylogenetic order.

\section{Arripidae (Pelagiaria: Scombriformes)}

One of the families not examined by the most recent large-scale phylogenies is the family Arripidae (Australasian salmons or kahawais). The family comprises a single genus, Arripis, with four putative species: A. georgianus, A. trutta, A. truttacea, and A. xylabion (Paulin, 1993). Previous studies on the taxonomic classification and relationships of the family are very few and controversial (Miya et al., 2013; Paulin, 1993; Yagishita et al., 2002b; Yagishita et al., 2009).

More than 80 years after the family was first recognized by Gill (1893; described as Arripididae), MacDonald (1983), in an unpublished dissertation, provided the preliminary hypothesis regarding the interrelationships within Arripidae based on allozyme markers. He hypothesized that $A$. trutta and $A$. truttaceus are sister-species, with this clade being sister to $A$. 
georgianus. Arripis xylabion was described in 1993, and therefore, was not included at the time (Paulin, 1993). Johnson and Fritzsche (1989) included one of the four species, A. georgianus, and some other percoids as outgroups to test the sister-group relationship between the nibblers, Graus and Girella (Family Kyphosidae, Subfamily Girellinae). Their choice of outgroups is based on Freihofer's (1963) examination of the ramus lateralis accessorius (RLA) nerve patterns, suggesting a close relationship between scorpidids (halfmoons), kyphosids (rudderfishes), girellids (nibblers), oplegnathiods (knifejaws), microcanthids, arripids, kuhliids (flagtails), teraponids (tigerperches), pomatomids (bluefishes), nemastistiids (roosterfishes), and several additional families belonging to Stromateoidea. In their morphological examination of the above groups, Johnson and Fritzsche (1989) concurred with Freihofer's hypothesis that RLA pattern 10 characterizes a natural assemblage. In an effort to evaluate the RLA pattern 10's usefulness as a phylogenetic marker within the percomorphs, Yagishita et al. (2009) analyzed the mitogenome sequences of 13 species, including A. trutta plus outgroups, exhibiting RLA pattern 10. They proposed two lineages for species with RLA pattern 10 and at least two independent origins for the character. Interestingly, they recovered a highly supported monophyletic group comprising Arripidae, Stromateoidei, and Scombridae.

This close relationship among the three families has been also implied in a previous study by Yagishita et al. (2002b), based on mtDNA sequences from Arripis georgianus; however, support for the group was weak (59\% BS). Yagishita et al. (2009) further noted that this morphologically diverse group is comprised of pelagic dwellers, often associated with long distance migrations. In their global EToL phylogeny, Betancur-R. et al. (2013a) obtained a wellsupported monophyletic group containing mainly pelagic families, which they grouped in the order Scombriformes. Miya et al. (2013) obtained similar results based on combined 
mitogenomic and nuclear sequence data and coined a different name for this clade, the Pelagia. In a recent update of the fish classification, Betancur-R. et al. (2014) adapted this clade name for the series (modified to Pelagiaria), retaining the name Scombriformes for its single component order.

In the present study, we were able to include all the three species investigated in the initial allozyme study and found our results to be consistent with MacDonald's (1983), placing A. trutta and A. truttacea as sister species and these sister to A. georgianus (Fig. 2). Our results also corroborate previous findings (Miya et al., 2013; Yagishita et al., 2002a; Yagishita et al., 2009) placing Arripidae within the pelagic dwellers and relatives (families Pomatomidae, Scombrolabracidae, Bramidae, Chiasmodontids, Icosteidae, Centrolophidae, Nomeidae, Stromateidae, Caristiidae, Ariommatidae, and Tetragonuridae). Our topology differs from that in Miya et al. (2013), however, with the Chiasmodontidae placed as the sister lineage of all remaining families in Pelagiaria. Our results also obtained a non-monophyletic Scombridae, but support for this is low. Arripidae is monophyletic, but identification of its sister group within Pelagiaria remains inconclusive due to insufficient resolution among early-branching lineages.

\section{Lactariidae (order-level incertae sedis in Carangaria)}

One of the families not examined by the recent large-scale molecular studies is the monotypic Lactariidae (false trevally). Jordan (1923) erected the family Lactariidae, placing it within the Carangiformes. While Jordan's classification (based on external morphology) has been widely accepted (Johnson, 1984; Smith-Vaniz, 1984), some previous reports associated the false trevallies with scombrids, pomatomids, and carangids (Bloch and Schneider 1801, Cuvier 1829, Valenciennes in Cuvier and Valenciennes 1833, Seale 1910), Sciaenidae (Günther, 1860), or 
Serranidae (Regan, 1913). More recently, Leis (1994) presented several morphological characters supporting close relationship between Lactariidae, Mene maculata (moonfish), and the carangoids, also suggesting a close affinity. In their assessment of the monophyly of the flatfishes (Pleuronectiformes), Campbell et al. (2013) provided molecular evidence of the placement of Lactarius within the Carangaria (carangimorphs). They recovered Lactarius in a clade with Sphyraena, Mene, Makaira, and Xiphias, but this node received poor statistical support. Betancur-R. and Orti (2014) conducted an analysis combining their previous dataset (Betancur-R. et al., 2013b) with that of Campbell et al. and recovered Lactarius sister to sphyraenids (60\% BS).

Our results corroborate the placement of lactariids in Carangaria (Fig. 3). We recovered the false trevally as sister to the moonfish (see Leis, 1994), but support for this is weak. We examined two individuals of L. lactarius from distant locations in the Indian (Qatar) and the Pacific (Fiji) oceans, and their estimated timing of divergence is ca. $13 \mathrm{Ma}$ (Fig. 3). These prominent divergences suggest that the monotypic Lactarius includes at least one cryptic species.

Finally, our analyses also provide molecular evidence for the monophyly of the order Pleuronectiformes (flatfishes), a result that has been elusive from previous large-scale phylogenetic analyses (Berendzen and Dimmick, 2002; Betancur-R et al., 2013b; Near et al., 2013; Pardo et al., 2005). A discussion on the molecular-based monophyly of pleuronectiforms is presented in Betancur-R. \& Ortí (2014). These results support the notion that addition of taxa can affect phylogenetic placement within rapid radiations (e.g., carangimorphs). Future assessment of morphological characters diagnosing this group will be key to understanding the relationships uniting the flatfishes, billfishes, and carangoids (Betancur-R et al., 2013a; Chen et al., 2003; 
Friedman, 2012; Ishiguro et al., 2003; Johnson, 1984; Leis, 1994; Li et al., 2009; Little et al., 2010; Smith and Wheeler, 2006).

\section{Hapalogenyidae (Eupercaria: Lobotiformes)}

The family of barbeled grunters, Hapalogenyidae, is one of the groups not examined by the recent large-scale molecular studies. The phylogenetic placement of the family within the percomorphs has been controversial (Iwatsuki and Nakabo, 2005; Iwatsuki et al., 2000; Johnson, 1984; Lindeman and Toxey, 2003; Ren and Zhang, 2007; Sanciangco et al., 2011; Springer and Raasch, 1995), with members in the family often placed in the Haemulidae (Iwatsuki and Russell, 2006; Iwatsuki et al., 2000; McKay, 2001; Nelson, 2006; Richardson, 1844) or classified as incertae sedis under the suborder Percoidei (Johnson, 1984). Springer and Raasch (1995) erected the family name, sic Hapalogenidae (also spelled Haplogeniidae) for the genus Hapalogenys, without providing strong supporting evidence. McKay (2001) and Iwatsuki and Russell (2006) recognized Hapalogenys separate from Haemulidae (grunts), but retained the genus in Haemulidae for convenience, pending further study of more genera. McKay (2001) noted similarities between Hapalogenys and members of Dinopercidae (cavebasses); however, he also observed that Hapalogenys lacks intrinsic muscles on the posterior part of the swimbladder. Leis and Carson-Ewart (2000) suggested that Lobotes, Datnioides, and Hapalogenys share remarkable similarities in larval morphology, particularly in the supination of head, pigmentation, early development of the posteriorly-placed pelvic fins, and general body shape. These authors placed the three genera in an informal group called "Lobotes-like." Ren and Zhang (2007), in their study of phylogenetic relationships of 15 haemulids based on 16S mtDNA sequences, recovered Hapalogenys outside Haemulidae. Sanciangco et al. (2011), Tavera et al. 
(2012) and Wei et al. (2014) corroborated this finding in their phylogenetic analysis of Haemulidae using mitogenomics and nuclear markers. These studies provided substantial molecular evidence indicating that Hapalogenys is indeed not a haemulid and confirmed Leis and Carson-Ewart (2000) hypothesis that place it close to Lobotes (Datnioides was not sampled in their study). Liang et al. (2012) also recovered Hapalogenys outside haemulids based on a much limited taxonomic sampling. Most previous studies, however, have included Hapalogenys as an outgroup species and none has tested nor included Hapalogenys in any molecular analysis implementing a broad taxonomic coverage of percomorphs.

The results of our RAxML analysis (Fig. 4) place the family Hapalogenyidae in the order Lobotiformes (sensu Betancur-R. et al., 2014), a well-supported clade (100\% BS) that includes lobotids and Datnioides, confirming some of the previous morphological and molecular hypotheses (Leis and Carson-Ewart, 2000; Sanciangco et al., 2011). We also obtained the lobotiform clade as the sister group of the Spariformes, an order erected by Bleeker and recently resurrected to include nemipterids, lethrinids, and sparids (Betancur-R. et al., 2013a; Betancur-R. et al., 2014). This sister-order relationship, however, has low statistical support (BS 34\%) and has not previously been obtained, possibly indicating a spurious grouping.

\section{Centracanthidae (synonym of Sparidae; Eupercaria: Spariformes)}

The inclusion of Centracanthidae (picarel porgies) Gill 1893 in our analysis confirms that this family should be treated as a junior synonym of Sparidae (porgies) Rafinesque 1818 (Fig. 4). There are currently two putative genera, namely Centracanthus (with one species) and Spicara (with nine species), belonging in Centracanthidae. Previous assessments of centracanthids have placed this family close to the Sparidae and to Inermia and Emmelichthyops (Heemstra, 1974). 
The latter genera are currently placed in the Haemulidae (grunts) but were formerly placed in their own family, Inermiidae (Johnson, 1981, 1984; Jordan and Fesler, 1893; Regan, 1913; Smith, 1938). In his delimitation of the family Emmelichthyidae (rovers), Heemstra (1974) placed Inermia and Emmelichthyops, along with several other genera in a separate family, Centracanthidae, diagnosed by the presence of a "joint-like articulation at the distal (ventral) ends of the premaxillary and maxillary bones." Johnson (1981) examined this joint and noted a significant difference in its articulation between that of the former inermiids and centracanthids. In centracanthids the distal end of the premaxillary gives rise to two flanges that form a trough that cradles the shaft of the maxillary anterior to a distal, ventral expansion, a condition shared by the closely related sparids. In "inermiids", the premaxillary fits into an acute notch in the ventral margin of the maxillary instead of having grooves where the maxillary is situated. Heemstra and Randall (1977) also corroborated this finding and noted that centracanthids are sparid derivatives, supported by the presence of sparoid suspensorium, infraorbital configuration, and six branchiostegals. Johnson (1981) further observed that Centracanthidae appears closely related to the Sparidae, not only based on similarity of the maxillary-premaxillary articulation, but also on a number of general osteological features. He noted that there are many morphological specializations associated with their planktivorous lifestyle, supporting the monophyly of Centracanthidae. Johnson retained the centracanthids in a separate family pending investigation of the interrelationships within the sparoids. Carpenter and Johnson (2002) recovered a monophyletic Sparidae plus Centracanthidae (Spicara maena, S. alta and Centracanthus cirrus) and found four non-homoplasious synapomorphies: three openings in the lateral wall of pars jugularis, a modified distal end of the alveolar ramus of the premaxillary articulating with the distal ventral edge of the maxilla, proximal tips of the first hypural and the 
parhypural broadly overlapping and articulating with the urostyle, and presence of apical pores in the scales of lateral line. The reciprocal monophyly of Sparidae plus Centracanthidae was further supported by subsequent molecular studies that included one or few members of the genus Spicara within Sparidae (Chiba et al., 2009; Day, 2002; Orrell and Carpenter, 2004; Orrell et al., 2002), but did not include Centracanthus.

Hanel and Tsigenopoulos (2011) conducted a molecular phylogenetic analysis of the sparids (15 genera) that included the two centracanthid genera using 16S mtDNA sequences. Their topology shows that members of centracanthids spread throughout the Sparidae family. They recovered Spicara melanurus nested within Diplodus. Although Spicara melanurus was not included in our molecular analysis, our morphological examination of S. melanurus shows that it is indeed a Diplodus with a highly protrusible jaw and a spot on the caudal peduncle, as in all other members of the genus. Spicara axillaris (also not sampled in our study) is placed close to Sparus auratus and Pachymetopon. Spicara maena, S. smaris, and S. flexuosa (not sampled) form a clade that is sister to Spondyliosoma. The phylogenetic hypothesis of Hanel and Tsigenopoulos (2011) placed Spicara alta at the base of the sparid clade. More recently, Santini et al. (2014) also recovered Spicara as polyphyletic within the Sparidae in a multi-locus phylogenetic analysis of the porgies.

In agreement with previous molecular studies (based on more restricted taxonomic sampling), our broad scale multi-locus analysis of the percomorphs shows that centracanthids are scattered throughout the sparids (Fig. 4). We also recovered Spicara maena and S. smaris together with Spondyliosoma. Spicara alta is also placed in a clade with Dentex,Pagellus, Argyrozona, Porcostoma, Chrysoblephus, Argyrops, Cheimerius, and Viridentex. We found S. nigricauda (not sampled in Hanel and Tsigenopoulos 2011) together with Diplodus, 
Lithognathus, and the rest of sparids. Our results differ from theirs in the placement of Centracanthus cirrus, which is placed in a clade together with Boops, Oblada, and Pachymetopon, but support for this is low. Examination of most genera of sparids and centracanthids in our analysis confirmed that centracanthids are indeed sparids. We sink the family Centracanthidae and recognize all previously classified centracanthids as members of Sparidae.

Centracanthidae was erected based on its planktivorous life style and highly protrusible jaw. Our study confirms that this trait is labile and evolved several times within the Sparidae. This morphological convergence arising from similar ecological responses is also observed in other eupercarian family pairs such as Lutjanidae-Caesionidae and Hamulidae-Inermiidae. With the inclusion of Spicara and Centracanthus, Sparidae is now monophyletic (100\% BS). Two sparid genera, Diplodus and Spicara, are however, not monophyletic. Furthermore, none of the putative subfamilies in Sparidae are monophyletic (Chiba et al., 2009; Hanel and Sturmbauer, 2000; Orrell and Carpenter, 2004; Smith and Heemstra, 1986). Our findings do not support the current subfamilial classification of sparids based on dentition, spinous and soft fin ray counts, scalation, and body coloration.

The newly expanded Sparidae, along with the families Nemipteridae (threadfin breams), and Lethrinidae (emperors), make up the order Spariformes. Akazaki (Akazaki, 1962) was the first to recognize the "spariforms" based on osteological features and dentition. Johnson (1981) expanded Akazaki's spariform and erected the superfamily "Sparoidea" to include the Nemipteridae, Lethrinidae, and the more specialized Sparidae plus Centracanthidae, based on similarity of maxillary-premaxillary distal articulation and other osteological characters. Based on cladistic analyses of 54 morphological characters, Carpenter and Johnson (2002) also 
recovered a monophyletic Sparoidea, substantiated by three non-homoplasious synapomorphies: symplectic with dorsal and ventral laminar extensions, broad articulation between hyomandibular and metapterygoid, and anterior extension of suborbital shelf behind second infraorbital. Our results are concordant with those of Johnson (1981) and Carpenter and Johnson (2002) regarding the recognition of spariforms (or sparoids).

\section{Bathyclupeidae and Symphysanodontidae (Eupercaria: Pempheriformes)}

The phylogenetic position of slopefishes among percomorphs has remained uncertain. Most information available regarding symphysanodontids pertain to species accounts and generalized descriptions for the members of the family (Anderson et al., 2011; Anderson, 2000, 2003; Anderson and Springer, 2005; Nelson, 1994, 2006). The family is comprised of a single genus, Symphysanodon, with 12 putative species (Anderson et al., 2011). Members of this family have been mistaken in the past for species of lanternbellies (Acropomatidae), sea basses (Serranidae), or snappers (Lutjanidae), but can easily be recognized by the absence of key characters that define these other groups (Anderson and Springer, 2005; Nelson, 1994, 2006). Johnson (1984) suggested an evolutionary affinity between acropomatids and the larvae of Symphysanodon sp., which he described as possessing hornlike frontal spines similar to those of Synagrops (Acropomatidae). Our results are concordant with Johnson's observation placing Symphysanodon close to acropomatids (Fig. 5). Notably, acropomatids are not monophyletic, with each of the three genera examined (Acropoma, Malaichthys, and Synagrops) branching off three different clades within the recently erected order Pempheriformes (sedis mutabilis sensu Betancur et al. 2013b).

Our study is also the first to include members of the family Bathyclupeidae in a molecular 
phylogenetic analysis of the percomorphs, placing it within the Pempheriformes (Fig. 5).

Although support for the pempheriform clade is weak (33\% BS), both here and in previous studies (hence 'sedis mutabilis'), its taxonomic composition is largely stable (Betancur-R et al., 2013a; Near et al., 2013). Notable differences include the addition of Creediidae (Limnichthys sp.) within Pempheriformes in most taxonomically-dense trees (this study; Betancur-R. et al.,

2015; Near et al., 2013), but not in the original EToL study (placed in Syngnatharia in BetancurR et al., 2013a). The original study had only four gene sequences for Limnichthys (two of which were likely contaminated) and this species is now represented in eight markers. The family Champsodontidae (represented by Champsodon snyderi) is also placed within the pempheriform clade here and in Near et al. (2013), but listed as order-level incertae sedis in Eupercaria by Betancur-R. et al. (2014).

\section{Dichistiidae (Eupercaria: Centrarchiformes: Terapontoidei)}

One of the families not included in the recent global phylogenies is the Dichistiidae (galjoen fishes). Like many perciform families, the taxonomic history of galjoen fishes has been controversial. The family is comprised of a single genus, Dichistius, with two putative species. Members of this family have been placed together with the squamipinnes, porgies, Girella, and Scorpis, based on superficial external characters (Jordan, 1923). Smith (1935) was the first to classify the galjoen fishes in a separate family, Dichistiidae (= Coracinidae), and placed them near the sea chubs, Girellidae and Kyphosidae (Leis and van der Lingen, 1997), a classification that has largely been followed in subsequent studies. There are several relationships hypothesized for galjoen fishes. Johnson (1984) placed them close to Drepaneidae (sicklefishes), but regarded them as ephippids based on overall similarity in gill arch characters. Nelson (1994) 
placed them close to sicklefishes (but not Ephippidae). Leis and van der Lingen (1997) rejected the placement of galjoen fishes in Sparidae and "Sparoidea", noting the absence of several diagnostic characters in these groups. Johnson (1984) and Johnson and Fritzsche (1989) observed that the larval features of the galjoen fishes are distinctive of the larval forms of the microcanthids, scorpidid, girellid, and kyphosids (MSG $+\mathrm{K})$. These authors also suggested that the MSG + K group is related to the families Arripidae (Australasian salmon), Kuhliidae (flagtails), Oplegnathidae (knifejaws), Terapontidae (tigerperches), and Stromateiodei. Leis and van der Lingen (1997) assessed the interrelationships of galjoen fishes to other families by looking at the Freihofer's pattern 10 of the ramus lateralis accessorius nerve (RLA) in larval forms. They concluded that the MSG $+\mathrm{K}$ families, as well as the families Dichistiidae and Arripidae, exhibit the RLA pattern 10. However, they found no additional information supporting the monophyly of the group or its relationships among other "perciforms."

Yagishita et al. (2009) examined the RLA pattern 10 of two perciform suborders (sensu Nelson 2006) that share this character. These include members of Percoidei, including Arripidae, Dichistiidae, Kyphosidae, Terapontidae, Kuhliidae, and Oplegnathidae, as well as members of the Stromateoidei. Their results, however, showed two independent origins for the facial nerve pattern, one in the group including Kyphosidae, Terapontidae, Kuhliidae, and Oplegnathidae, and another one in the group including Arripidae and Stromateoidei. Interestingly, they recovered Arripidae and Stromateoidei together with Scombridae (mackerels and tunas) and allies, which do not possess the RLA pattern 10. This group corroborates an earlier molecular study that examined the venom evolution in fishes (Smith and Wheeler, 2006). Smith and Wheeler (2006) provided a hypothesis of venom evolution sampled from a wide selection of percomorphs, including galjoen fishes. They obtained a clade including Dichistiidae, 
Kyphosidae, Oplegnathidae, Kuhliidae, Terapontidae, Creediidae (sandburrowers), and Uranoscopidae (stargazers). Our results corroborate many of these previous findings (Johnson and Fritzsche, 1989; Leis and van der Lingen, 1997; Smith and Wheeler, 2006; Yagishita et al., 2009), indicating that Dichistiidae is close to Kyphosidae, Girellidae, Ophlegnathidae, Kuhliidae, and Terapontidae (Fig. 6). These six families are now placed in the recently defined suborder Terapontoidei (99\% BS) within Centrarchiformes (sensu Betancur et al. 2014). Circumscription of Centrarchiformes follows recent classification proposals (Chen et al., 2014; Lavoue et al., 2014; Near et al., 2013).

\section{Latridae, Aplodactylidae, and Chironemidae (Eupercaria: Centrarchiformes: Cirrhitoidei)}

The inclusion of three additional families, Latridae (trumpeters), Aplodactylidae (marblefishes), and Chironemidae (kelpfishes) in this study confirmed previous hypotheses regarding cirrhitiform relationships (Fig. 6). These three families, together with Cheilodactylidae (morwongs) and Cirrhitidae (hawkfishes), represent the monophyletic suborder Cirrhitoidei sensu Betancur-R. et al. 2014 (= superfamily Cirrhitoidea sensu Burridge and Smolenski, 2004; Greenwood, 1995; Regan, 1912). Although monophyly of cirrhitoids has been widely accepted, the relationships within the group remain equivocal (Burridge and Smolenski, 2004; Greenwood, 1995). Greenwood (1966) inferred a close affinity among these five families but offered no information on interfamilial relationships. Greenwood (1995) subsequently provided a tentative hypothesis of relationships among cirrhitoid families, placing the Cirrhitidae as the earliest branching lineage, followed by the Chironemidae and by an unresolved trichotomy comprising Aplodactylidae, Cheilodactylidae, and Latridae.

Our results indicate that the family Cheilodactylidae is not monophyletic, with species 
branching off from two different clades. One group is comprised of the South African cheilodactylids (Cheilodactylus fasciatus and C. pixi) together with aplodactylids and chironemids (54\% BS); the other group includes $C$. variegatus, $C$. brachydactylus, and $C$. jessicalenorum together with the latrids (100\% BS). This finding was first reported by Burridge and Smolenski (2004). They noted that the South African Cheilodactylus can be distinguished from the rest of cheilodactylids by having a higher lateral line scale count and the presence of scales on the postcleithrum (Lamb 1990 in Burridge and Smolenski 2004). They also noted that other members of cheilodactylids are undistinguishable from the latrids. Burridge and Smolenski (2004) proposed to redefine the familial classification of these (non-South African) cheilodactylids, and included them in their "expanded Latridae." Because the South African Cheilodactylus fasciatus is the type species of both Cheilodactylus and Cheilodactylidae, this expanded group would require a generic and familial reassignment accompanied by a new diagnosis (Burridge and Smolenski, 2004). Their preliminary assessment of the dorsal pterygiophore insertion for the expanded Latridae suggests that this group possesses two predorsal bones, both of which are anterior to the first neural spine and located anterior to the first pterygiophore. Our results also confirm the monophyly of Cirrhitoidei (100\% BS), with Cirrhitidae forming the sister group of the rest of the families in the suborder, corroborating the morphological hypothesis of Greenwood (1995).

\section{Conclusions}

In this study, we infer phylogenetic placement for seven percomorph families and augment the taxonomic diversity in the global fish phylogeny (10 families and 49 species). We used two mitochondrial genes (COI and Cyt $b$ ), in addition to the 21-gene EToL dataset, and restricted our 
taxonomic sampling to Percomorphaceae. While our analysis did not resolve the recalcitrant rapid radiations in this group, it nevertheless provided increased resolution for some clades at different taxonomic levels. For instance, the new tree resolves the monophyly of Pleuronectiformes, Polyprionidae, and Blennioidei, a result that has been elusive from our previous global phylogenetic assessments (Fig. S1).

Examination of enigmatic taxa adds novel insights into the relationships of percomorphs and contributes to our phylogenetic classification of fishes (Betancur-R. et al., 2013; Betancur-R. et al., 2014), a resource that has gained significant traction in recent years and has been adopted by popular databases, such as NCBI (http://www.ncbi.nlm.nih.gov), Encyclopedia of Life (http://www.eol.org), Paleobiology Database (https://paleobiodb.org), and by other studies (e.g., Lavoue et al., 2014; Ng et al., 2015; Ruggiero et al., 2015). Our phylogenetic hypothesis, based on the most comprehensive percomorph dataset compiled to date, also provides a guide to direct future sampling and sequencing efforts. Future studies incorporating broader taxonomic sampling and deeper genomic coverage will help in unraveling the complex phylogenetic affinities within clades of percomorphs (Gilbert et al., 2015).

\section{Acknowledgements}

We are grateful to several colleagues for providing tissue samples for this study: A. Bentley

(Biodiversity Institute, U. Kansas), C. Struthers (Museum of New Zealand, Te Papa Tongarewa), Y. Iwatsuki (U. Miyazaki), P.A. Hastings and H.J. Walker (SIO), S. Knudsen (U Auckland), C. Burridge (U Tasmania), T. Darden (Marine Resources Research Institute, South Carolina Department of Natural Resources), M. McGrouther (Australian Museum), and B. Stockwell (ODU). We thank W.N. Eschmeyer, and J. Fong for providing access to their Catalog of Fishes 
database. We are also thankful to E. Womack (ODU) for performing independent lab work for some of the sequences as part of our quality control protocol. MS would like to thank A. Cobos and J. Raynal for suggestions on improving the manuscript. MS would also like to thank the following programs for her training: NimBIOS, Bodega Bay, Deepfin, and NESCent. MS is also grateful to L. Weigt (Smithsonian Institution, LAB) and G. Orti (GWU) for allowing her to process some of her samples in their laboratories. This manuscript is part of MS's dissertation and the authors' other contribution to the EToL project. The support for this project is from NSF awards DEB-0732894 to KC, and DEB-1457184 and DEB-1541491 to RBR. 


\section{Figure Captions}

Fig 1. Phylogeny of the nine major percomorph clades in the Subdivision Percomorphaceae. Each major clade is recognized as a series (sensu Betancur-R. et al., 2013a; Betancur-R. et al., 2014). Values in parentheses indicate total number of orders, total number of families, and the approximate number of valid species included in each series. Due to some families having uncertain ordinal affiliation (order-level insertae sedis), for some series the ">" sign precedes the actual number of orders listed. The phylogenetic placement for the ten families newly examined here is shown in blue. See also Figs. 2-6 for detailed relationships on selected percomorph clades. The complete phylogeny with bootstrap support values is reported in Fig. S1. Copyright: fish illustrations were obtained from FAO (drawings by Manuela DAntoni) are reproduced with permission.

Fig. 2. Detailed relationships among families in the order Scombriformes (series Pelagiaria). Newly examined taxa are shown in blue. Copyright: fish illustrations were obtained from FAO (drawings by Manuela DAntoni) are reproduced with permission.

Fig. 3. Detailed relationships among families and orders in the series Carangaria. Newly examined taxa are shown in blue. Copyright: fish illustrations were obtained from FAO (drawings by Manuela DAntoni) are reproduced with permission.

Fig. 4. Detailed relationships among families in the orders Lobotiformes and Spariformes (series Eupercaria). Newly examined taxa are shown in blue. Copyright: fish illustrations were obtained from FAO (drawings by Manuela DAntoni) are reproduced with permission.

Fig. 5. Detailed relationships among families in the order Pempheriformes (series Eupercaria). Newly examined taxa are shown in blue. Copyright: fish illustrations were obtained from FAO (drawings by Manuela DAntoni) are reproduced with permission.

Fig. 6. Detailed relationships among families in the order Centrarchiformes (series Eupercaria). Newly examined taxa are shown in blue. Copyright: fish illustrations were obtained from FAO (drawings by Manuela DAntoni) are reproduced with permission. 


\section{References}

Akazaki, M., 1962. Studies on the spariform fishes - Anatomy, phylogeny, ecology and taxonomy. Misaki Marine Biological Institute, Kyoto University., pp. 1-368.

Alfaro, M.E., Santini, F., Brock, C., Alamillo, H., Dornburg, A., Rabosky, D.L., Carnevale, G., Harmon, L.J., 2009. Nine exceptional radiations plus high turnover explain species diversity in jawed vertebrates. Proceedings of the National Academy of Sciences of the United States of America 106, 13410-13414.

Anderson, W., Jr., Baranes, A., Goren, M., 2011. Redescription of the perciform fish Symphysanodon disii (Symphysanodontidae) from the Gulf of Aqaba, Red Sea, with comments on S. pitondelafournaisei and sexual dimorphism in the genus. Zootaxa 3027, 1-8.

Anderson, W.D., Jr., 2000. Symphysanodontidae. In: Carpenter, K.E., Niem, V.H. (Eds.), FAO Species Identification Guide for Fishery Purposes. The Living Marine Resources of the Western Central Pacific Vol. 4. Bony Fishes Part 2 (Mugilidae to Carangidae), Food and Agriculture Organization of the United Nations, Rome, pp. 2438-2441.

Anderson, W.D., Jr., 2003. Symphysanodontidae. In: Carpenter, K.E. (Ed.), The Living Marine Resources of the Western Central Atlantic. Vol. 2. Bony Fishes Part 1 (Acipenseridae to Grammatidae), Food and Agriculture Organization of the United Nations, Rome, pp. 1304-1307.

Anderson, W.D., Jr., Springer, V.G., 2005. Review of the perciform fish genus Symphysanodon Bleeker (Symphysanodontidae), with descriptions of three new species, S. mona, S. parini, and $S$. rhax. Zootaxa 996, 1-44.

Arcila, D., Alexander Pyron, R., Tyler, J.C., Ortí, G., Betancur-R, R., 2015. An evaluation of fossil tip-dating versus node-age calibrations in tetraodontiform fishes (Teleostei: Percomorphaceae). Molecular phylogenetics and evolution 82, 131-145.

Berendzen, P.B., Dimmick, W.W., 2002. Phylogenetic relationships of Pleuronectiformes based on molecular evidence. Copeia, 642-652.

Betancur-R, R., Broughton, R.E., Wiley, E.O., Carpenter, K., Lopez, J.A., Li, C., Holcroft, N.I., Arcila, D., Sanciangco, M., Cureton Ii, J.C., Zhang, F., Buser, T., Campbell, M.A., Ballesteros, J.A., Roa-Varon, A., Willis, S., Borden, W.C., Rowley, T., Reneau, P.C., Hough, D.J., Lu, G., Grande, T., Arratia, G., Orti, G., 2013a. The tree of life and a new classification of bony fishes. PLoS currents 5.

Betancur-R, R., Li, C., Munroe, T.A., Ballesteros, J.A., Orti, G., 2013b. Addressing gene tree discordance and non-stationarity to resolve a multi-locus phylogeny of the flatfishes (Teleostei: Pleuronectiformes). Systematic Biology 62, 763-785. 
Betancur-R, R., Wiley, E., Miya, M., Lecointre, G., Bailly, N., Ortí, G., 2013c. New and Revised Classification of Bony Fishes Version 2 (http://www.deepfin.org/Classification_v2.htm).

Betancur-R., R., Orti, G., 2014. Molecular evidence for the monophyly of flatfishes (Carangimorpharia: Pleuronectiformes). Molecular phylogenetics and evolution 73, 18-22.

Betancur-R., R., Orti, G., Pyron, A.R., 2015. Fossil-based comparative analyses reveal ancient marine ancestry erased by extinction in ray-finned fishes. Ecology letters 18, 441-450.

Betancur-R., R., Wiley, E.O., Miya, M., Lecointre, G., Orti, G., 2014. Phylogenetic Classification of Bony Fishes. Version 3.

Burridge, C.P., Smolenski, A.J., 2004. Molecular phylogeny of the Cheilodactylidae and Latridae (Perciformes: Cirrhitoidea) with notes on taxonomy and biogeography. Molecular Phylogenetics and Evolution 30, 118-127.

Campbell, M.A., Chen, W.-J., Lopez, J.A., 2013. Are flatfishes (Pleuronectiformes) monophyletic? Molecular Phylogenetics and Evolution 69, 664-673.

Carpenter, K.E., Johnson, G.D., 2002. A phylogeny of sparoid fishes (Perciformes, Percoidei) based on morphology. Ichthyological Research 49, 114-127.

Chen, W.-J., Bonillo, C., Lecointre, G., 2003. Repeatability of clades as a criterion of reliability: a case study for molecular phylogeny of Acanthomorpha (Teleostei) with larger number of taxa. Molecular Phylogenetics and Evolution 26, 262-288.

Chen, W.-J., Lavoué, S., Beheregaray, L.B., Mayden, R.L., Riddle, B., 2014. Historical biogeography of a new antitropical clade of temperate freshwater fishes. Journal of Biogeography 41, 1806-1818.

Chiba, S.N., Iwatsuki, Y., Yoshino, T., Hanzawa, N., 2009. Comprehensive phylogeny of the family Sparidae (Perciformes: Teleostei) inferred from mitochondrial gene analyses. Genes Genet. Syst. 84, 153-170.

Day, J.J., 2002. Phylogenetic relationships of the Sparidae (Teleostei: Percoidei) and implications for convergent trophic evolution. Biological Journal of the Linnean Society 76, 269-301.

Dettai, A., Bailly, N., Vignes-Lebbe, R., Lecointre, G., 2004. Metacanthomorpha: essay on a phylogeny-oriented database for morphology--the acanthomorph (Teleostei) example. Systematic Biology 53, 822-834.

Dettai, A., Lecointre, G., 2005. Further support for the clades obtained by multiple molecular phylogenies in the acanthomorph bush. C. R. Biol. 328 674-689. 
Freihofer, W.C., 1963. Patterns of the ramus lateralis accessorius and their systematic significance in teleostean fishes. Stanford Ichthyological Bulletin 8, 80-189.

Friedman, M., 2010. Explosive morphological diversification of spiny-finned teleost fishes in the aftermath of the end-Cretaceous extinction. Proceedings of the Royal Society B-Biological Sciences 277, 1675-1683.

Friedman, M., 2012. Osteology of $\dagger$ Heteronectes chaneti (Acanthomorpha, Pleuronectiformes), an Eocene stem flatfish, with a discussion of flatfish sister-group relationships. Journal of Vertebrate Paleontology 32, 735-756.

Gilbert, P.S., Chang, J., Pan, C., Sobel, E.M., Sinsheimer, J.S., Faircloth, B.C., Alfaro, M.E., 2015. Genome-wide ultraconserved elements exhibit higher phylogenetic informativeness than traditional gene markers in percomorph fishes. Molecular phylogenetics and evolution 92, 140146.

Gill, T.N., 1893. A comparison of antipodal faunas. Memoirs of the National Academy of Sciences 6, 91-124.

Greenwood, P.H., 1995. A revised familial classification for certain cirrhitoid genera (Teleostei, Percoidei Cirrhitoidea), with comments on the group's monophyly and taxonomic ranking. Bulletin of The Natural History Museum Zoology Series 61, 1-10.

Greenwood, P.H., Rosen, D.E., Weitzman, S.H., Myers, G.S., 1966. Phyletic studies of teleostean fishes, with a provisional classification of living forms. Bulletin of the American Museum of Natural History 131, 339-456.

Günther, A., 1860. Catalogue of the fishes in the British Museum. Catalogue of the acanthopterygian fishes in the collection of the British Museum. Squamipinnes, Cirrhitidae, Triglidae, Trachinidae, Sciaenidae, Polynemidae, Sphyraenidae, Trichiuridae, Scombridae, Carangidae, Xiphiidae. British Museum, London.

Hanel, R., Sturmbauer, C., 2000. Multiple Recurrent Evolution of Trophic Types in Northeastern Atlantic and Mediterranean Seabreams (Sparidae, Percoidei). Journal of Molecular Evolution 50, 276-283.

Hanel, R., Tsigenopoulos, C.S., 2011. Phylogeny, evolution, and taxonomy of sparids with some notion their ecology and biology. In: Pavlidis, M., Mylonas, C. (Eds.), Sparidae: Biology and aquaculture of gilthead sea bream and other species (Google eBook). John Wiley \& Sons, p. 416.

Heemstra, P.C., 1974. On the identity of certain eastern Pacific and Caribbean post-larval fishes (Perciformes) described by Henry Fowler. Proceedings of the Academy of Natural Sciences of Philadelphia 126.

Heemstra, P.C., Randall, J.E., 1977. A revision of the Emmelichthyidae (Pisces: Perciformes). Australian Journal of Marine and Freshwater Research 28, 361-396. 
Ishiguro, N.B., Miya, M., Nishida, M., 2003. Basal euteleostean relationships: a mitogenomic perspective on the phylogenetic reality of the "Protacanthopterygii'. Molecular Phylogenetics and Evolution 27, 476-488.

Iwatsuki, Y., Nakabo, T., 2005. Redescription of Hapalogenys nigripinnis (Schlegel in Temminck and Schlegel, 1843), a senior synonym of $H$. nitens Richardson, 1844, and a new species from Japan. Copeia 4, 854-867.

Iwatsuki, Y., Russell, B.C., 2006. Revision of the genus Hapalogenys (Teleostei: Perciformes) with two new species from the Indo-West Pacific. Memoirs of Museum Victoria 63, 29-46.

Iwatsuki, Y., Satapoomin, U., Amaoka, K., 2000. New Species: Hapalogenys merguiensis (Teleostei; Perciformes) from Andaman Sea. Copeia 2000, 129-139.

Johnson, G.D., 1981. The limits and relationships of the Lutjanidae and associated families. Bulletin of the Scripps Institution of Oceanography 24, 1-114.

Johnson, G.D., 1984. Percoidei: development and relationships. In: Moser, H.G., Richards, W.J., Cohen, D.M., Fahay, M.P., Kendall, A.W., Jr. Richardson, S.L. (Eds.). American Society of Ichthyologists and Herpetologists, pp. 464-498.

Johnson, G.D., 1993. Percomorph phylogeny: progress and problems. Bulletin of Marine Science 52, 3- 28.

Johnson , G.D., Fritzsche, R.A., 1989. Graus nigra, an omnivorous girellid, with a comparative osteology and comments on relationships of the Girellidae (Pisces: Perciformes). Proceedings of the Academy of Natural Sciences of Philadelphia 141, 1-27.

Johnson, G.D., Patterson, C., 1993. Percomorph phylogeny: a survey of acanthomorphs and a new proposal. Bulletin of Marine Science 52, 554-626.

Jordan, D.S., 1923. A classification of fishes including families and genera as far as known. Stanford Univ. Publ., Univ. Ser. Biol. Sci. 3, 77-243.

Jordan, D.S., Fesler, B., 1893. A review of the sparoid fishes of American and Europe. Report U.S. Comm. Fish and Fisheries for 1889-1891.

Kawahara, R., Miya, M., Mabuchi, K., Lavoue, S., Inoue, J.G., Satoh, T.P., Kawaguchi, A., Nishida, M., 2008. Interrelationships of the 11 gasterosteiform families (sticklebacks, pipefishes, and their relatives): A new perspective based on whole mitogenome sequences from 75 higher teleosts. Molecular phylogenetics and evolution 46, 224-236.

Lauder, G.V., Liem, K.F., 1983. The evolution and interrelationships of the actinopterygian fishes. Bulletin of The Museum of Comparative Zoology 150, 95-197. 
Lautredou, A.C., Motomura, H., Gallut, C., Ozouf-Costaz, C., Cruaud, C., Lecointre, G., Dettai, A., 2013. New nuclear markers and exploration of the relationships among Serraniformes (Acanthomorpha, Teleostei): the importance of working at multiple scales. Molecular Phylogenetics and Evolution 67, 140-155.

Lavoue, S., Nakayama, K., Jerry, D.R., Yamanoue, Y., Yagishita, N., Suzuki, N., Nishida, M., Miya, M., 2014. Mitogenomic phylogeny of the Percichthyidae and Centrarchiformes (Percomorphaceae): comparison with recent nuclear gene-based studies and simultaneous analysis. Gene 549, 46-57.

Leis, J.M., 1994. Larvae, adults and relationships of the monotypic perciform fish family Lactariidae. Records of the Australian Museum 46, 131-143.

Leis, J.M., Carson-Ewart, B.M., 2000. The larvae of Indo-Pacific coastal fishes. An identification guide to marine fish larvae. Fauna Malesiana Handbooks 2.

Leis, J.M., van der Lingen, C.D., 1997. Larval development and relationships of the perciform family Dichistiidae (=Coracinidae), the galjoen fishes. Bulletin of Marine Science 60, 100-116.

Li, B., Dettaï, A., Cruaud, C., Couloux, A., Desoutter-Meniger, M., Lecointre, G., 2009. RNF213, a new nuclear marker for acanthomorph phylogeny. Molecular Phylogenetics and Evolution 50, 345-363.

Li, C., Betancur-R, R., Smith, W.L., Orti, G., 2011. Monophyly and interrelationships of Snook and Barramundi (Centropomidae sensu Greenwood) and five new markers for fish phylogenetics. Mol Phylogenet Evol 60, 463-471.

Li, C., Lu, G., Ortí , G., 2008. Optimal data partitioning and a test case for ray-finned fishes (Actinopterygii) based on ten nuclear loci. Systematic Biology 57, 519-539.

Liang, R., Zhuo, X., Yang, G., Luo, D., Zhong, S., Zou, J., 2012. Molecular phylogenetic relationships of family Haemulidae (Perciformes: Percoidei) and the related species based on mitochondrial and nuclear genes. Mitochondrial DNA 23, 264-277.

Lindeman, K.C., Toxey, C., 2003. Haemulidae - Grunts. In: Carpenter, K.E. (Ed.), The living marine resources of the Western Central Atlantic. FAO species identification guide for fishery purposes and American Society of Ichthyologists and Herpetologists Special Publication No. 5, FAO, Rome, Italy, pp. 1375-2127.

Little, A.G., Lougheed, S.C., Moyes, C.D., 2010. Evolutionary affinity of billfishes (Xiphiidae and Istiophoridae) and flatfishes (Plueronectiformes): Independent and trans-subordinal origins of endothermy in teleost fishes. Molecular Phylogenetics and Evolution 56, 897-904.

MacDonald, C.M., 1983. Taxonomic and evolutionary studies on marine fishes of the genus Arripis (Perciformes: Arripidae). Bulletin of Marine Science 33, 780. 
Mahon, A.R., 2007. Molecular phylogenetics of perciform fishes using the nuclear recombination activating gene 1. PhD Dissertation. Old Dominion University, Norfolk, Virginia, USA, p. 303.

McKay, R.J., 2001. Haemulidae (= Pomadasyidae). Grunts (also sweetlips, rubberlips, hotlips, and velvetchins). In: Carpenter, K.E. (Ed.), FAO species identification guide for fishery purposes. The living marine resources of the Western Central Pacific. FAO, Rome, Italy, p. 589.

Miya, M., Friedman, M., Satoh, T.P., Takeshima, H., Sado, T., Iwasaki, W., Yamanoue, Y., Nakatani, M., Mabuchi, K., Inoue, J.G., Poulsen, J.Y., Fukunaga, T., Sato, Y., Nishida, M., 2013. Evolutionary origin of the scombridae (tunas and mackerels): members of a paleogene adaptive radiation with 14 other pelagic fish families. PloS one 8, e73535.

Miya, M., Kawaguchi, A., Nishida, M., 2001. Mitogenomic exploration of higher teleostean phylogenies: A case study for moderate-scale evolutionary genomics with 38 newly determined complete mitochondrial DNA sequences. Molecular Biology and Evolution 18, 1993-2009.

Miya, M., Satoh, T.P., Nishida, M., 2005. The phylogenetic position of toadfishes (order Batrachoidiformes) in the higher ray-finned fish as inferred from partitioned Bayesian analysis of 102 whole mitochondrial genome sequences. Biological Journal of the Linnean Society 85, 289306.

Miya, M., Takeshima, H., Endo, H., Ishiguro, N.B., Inoue, J.G., Mukai, T., Satoh, T.P., Yamaguchi, M., Kawaguchi, A., Mabuchi, K., Shirai, S.M., Nishida, M., 2003. Major patterns of higher teleostean phylogenies: a new perspective based on 100 complete mitochondrial DNA sequences. Molecular Phylogenetics and Evolution 26, 121-138.

Near, T.J., Dornburg, A., Eytan, R.I., Keck, B.P., Smith, W.L., Kuhn, K.L., Moore, J.A., Price, S.A., Burbrink, F.T., Friedman, M., Wainwright, P.C., 2013. Phylogeny and tempo of diversification in the superradiation of spiny-rayed fishes. Proceedings of the National Academy of Sciences of the United States of America.

Near, T.J., Eytan, R.I., Dornburg, A., Kuhn, K.L., Moore, J.A., Davis, M.P., Wainwright, P.C., Friedman, M., Smith, W.L., 2012a. Resolution of ray-finned fish phylogeny and timing of diversification. Proceedings of the National Academy of Sciences of the United States of America 109, 13698-13703.

Near, T.J., Sandel, M., Kuhn, K.L., Unmack, P.J., Wainwright, P.C., Smith, W.L., $2012 b$. Nuclear gene-inferred phylogenies resolve the relationships of the enigmatic Pygmy Sunfishes, Elassoma (Teleostei: Percomorpha). Mol Phylogenet Evol 63, 388-395.

Nelson, G., 1989a. Phylogeny of major fish groups. In: Fernholm, B., Bremer, K., Brundin, L., Jörnvall, H., Rutberg, L., Wanntorp, H.E. (Eds.), The Hierarchy of Life. Elsevier Science, Amsterdam, pp. 325-336. 
Nelson, G.J., 1989b. Phylogeny of major fish groups. In: Femholm, B., Bremer, K., Jomvall, H. (Eds.), The hierarchy of life, Excerpta Medica, Amsterdam., pp. 325-336.

Nelson, J.S., 1994. Fishes of the World. John Wiley \& Sons, Inc., Hoboken, New Jersey. Nelson, J.S., 2006. Fishes of the World Fourth Edition. John Wiley \& Sons, Inc., Hoboken, New Jersey.

Ng, H., Tan, H., Lim, K., Ludt, W.B., Chakrabarty, P., 2015. Fishes of the Eastern Johor Strait. Raffles Bulletin of Zoology 31, 303-337.

Orrell, T.M., Carpenter, K.E., 2004. A phylogeny of the fish family Sparidae (porgies) inferred from mitochondrial sequence data. Molecular Phylogenetics and Evolution 32, 425-434.

Orrell, T.M., Carpenter, K.E., Musick, J.A., Graves, J.E., 2002. Phylogenetic and biogeographic analysis of the Sparidae (Perciformes: Percoidei) from cytochrome $b$ sequences. Copeia 2002, 618-631.

Pardo, B.G., Machordom, A., Porto-Foresti, F., Sánchez, L., Foresti, F., Azevedo, M.F.C., Martínez, P., 2005. Phylogenetic analysis of flatfish (Order Pleuronectiformes) based on mitochondrial 16s rDNA sequences. Scientia Marina 69, 531-543.

Paulin, C., 1993. Review of the Australian fish family Arripididae (Percomorpha), with the description of a new species. Australian Journal of Marine and Freshwater Research 44, 459471.

Regan, C., 1912. The classification of the teleostean fishes of the order Pediculati. Annals and Magazine of Natural History, Series 8, 277 - 289.

Regan, C.T., 1913. On the classification of the percoid fishes. Annals and Magazine of Natural History 8, 111-145.

Ren, G., Zhang, Q., 2007. Phylogeny of haemulid with discussion on systematic position of the genus Hapalogenys. Acta Zootaxonomica Sinica 32, 835-841.

Richardson, J., 1844. Description of a genus of Chinese fish. Annals and Magazine of Natural History 13, 461-462.

Ruggiero, M.A., Gordon, D.P., Orrell, T.M., Bailly, N., Bourgoin, T., Brusca, R.C., CavalierSmith, T., Guiry, M.D., Kirk, P.M., 2015. A Higher Level Classification of All Living Organisms. PloS one 10, e0119248.

Sanciangco, M.D., Rocha, L.A., Carpenter, K.E., 2011. A molecular phylogeny of the Grunts (Perciformes: Haemulidae) inferred using mitochondrial and nuclear genes. Zootaxa 2966, 3750. 
Santini, F., Carnevale, G., Sorenson, L., 2014. First multi-locus timetree of seabreams and porgies (Percomorpha: Sparidae). Italian Journal of Zoology 81, 55-71.

Smith, H.M., 1935. The "Galjoen" fishes of South Africa. Transactions of the Royal Society of South Africa 23, 265-276.

Smith, J.L.B., 1938. The South African fishes of the families Sparidae and Denticidae. Trans. R. Soc. S. Afr. 26, 225-305.

Smith, M.M., Heemstra, P.C., 1986. Smith's sea fishes, Macmillan South Africa, Johannesburg. Smith, S.A., O’Meara, B.C., 2012. treePL: Divergence time estimation using penalized likelihood for large phylogenies. Bioinformatics (Oxford, England) 28, 2689-2690.

Smith, W.L., Craig, M., 2007. Casting the percomorph net widely: The importance of broad taxonomic sampling in the search for the placement of serranid and percid fishes. Copeia 2007, $35-55$.

Smith, W.L., Wheeler, W.C., 2006. Venom evolution widespread in fishes: Venom evolution widespread in fishes: A phylogenetic road map for the bioprospecting of piscine venoms. Journal of Heredity 97, 206-217.

Smith-Vaniz, W.F., 1984. Carangidae: relationships. In: Moser, H.G., Richards, W.J., Cohen, D.M., Fahay, M.P., Kendell Jr., A.W., Richardson, S.L. (Eds.), Ontogeny and Systematics of Fishes. Am. Soc. Ichthyo. Herpe. Spec. Publ. , pp. 640-670.

Springer, V.G., Johnson, G.D., 2004. Study of the dorsal gill-arch musculature of teleostome fishes, with special reference to Actinopterygii. Bulletin of the Biological Society of Washington $11,1-235$.

Springer, V.G., Raasch, M.S., 1995. Fishes, angling, and finfish fisheries on stamps of the world. American Topical Association, Tucson, Arizona.

Stamatakis, A., 2006. RAxML-VI-HPC: maximum likelihood-based phylogenetic analyses with thousands of taxa and mixed models. Bioinformatics (Oxford, England) 22, 2688-2690.

Tavera, J.J., Acero, A., Balart, E.F., Bernardi, G., 2012. Molecular phylogeny of grunts (Teleostei, Haemulidae), with an emphasis on the ecology, evolution, and speciation history of New World species. BMC evolutionary biology 12.

Thacker, C.E., 2009. Phylogeny of Gobioidei and placement within Acanthomorpha, with a new classification and investigation of diversification and character evolution. Copeia 2009, 93-104.

Vaidya, G., Lohman, D.J., Meier, R., 2011. SequenceMatrix: concatenation software for the fast assembly of multi-gene datasets with character set and codon information. Cladistics 27, 171180. 
Wainwright, P.C., Smith, W.L., Price, S.A., Tang, K.L., Sparks, J.S., Ferry, L.A., Kuhn, K.L., Eytan, R.I., Near, T.J., 2012. The evolution of pharyngognathy: a phylogenetic and functional appraisal of the pharyngeal jaw key innovation in labroid fishes and beyond. Systematic Biology 61, 1001-1027.

Wei, T., Sun, Y., Zhang, B., Wang, R., Xu, T., 2014. A mitogenomic perspective on the phylogenetic position of the Hapalogenys genus (Acanthopterygii: Perciformes) and the evolutionary origin of Perciformes. PloS one 9, e103011.

Wiley, E.O., Johnson, G.D., 2010. A teleost classification based on monophyletic groups. In: Nelson, J.S., Schultze, H.-P., Wilson, M.V.H. (Eds.), Origin and phylogenetic interrelationships of teleosts. Verlag Dr. Friedrich Pfeil, München, Germany, pp. 123-182.

Yagishita, N., Kobayashi, T., Nakabo, T., 2002a. Review of monophyly of the Kyphosidae (sensu Nelson, 1994), inferred from the mitochondrial ND2 gene. Ichthyological Research 49, 103-108.

Yagishita, N., Kobayashi, T., Nakabo, T., 2002b. Review of monophyly of the Kyphosidae (sensu Nelson, 1994), inferred from the mitochondrial ND2 gene. Ichthyological Research 49, 103-108.

Yagishita, N., Miya, M., Yamanoue, Y., Shirai, S.M., Nakayama, K., Suzuki, N., Satoh, T.P., Mabuchi, K., Nishida, M., Nakabo, T., 2009. Mitogenomic evaluation of the unique facial nerve pattern as a phylogenetic marker within the percifom fishes (Teleostei: Percomorpha). Molecular phylogenetics and evolution 53, 258-266. 


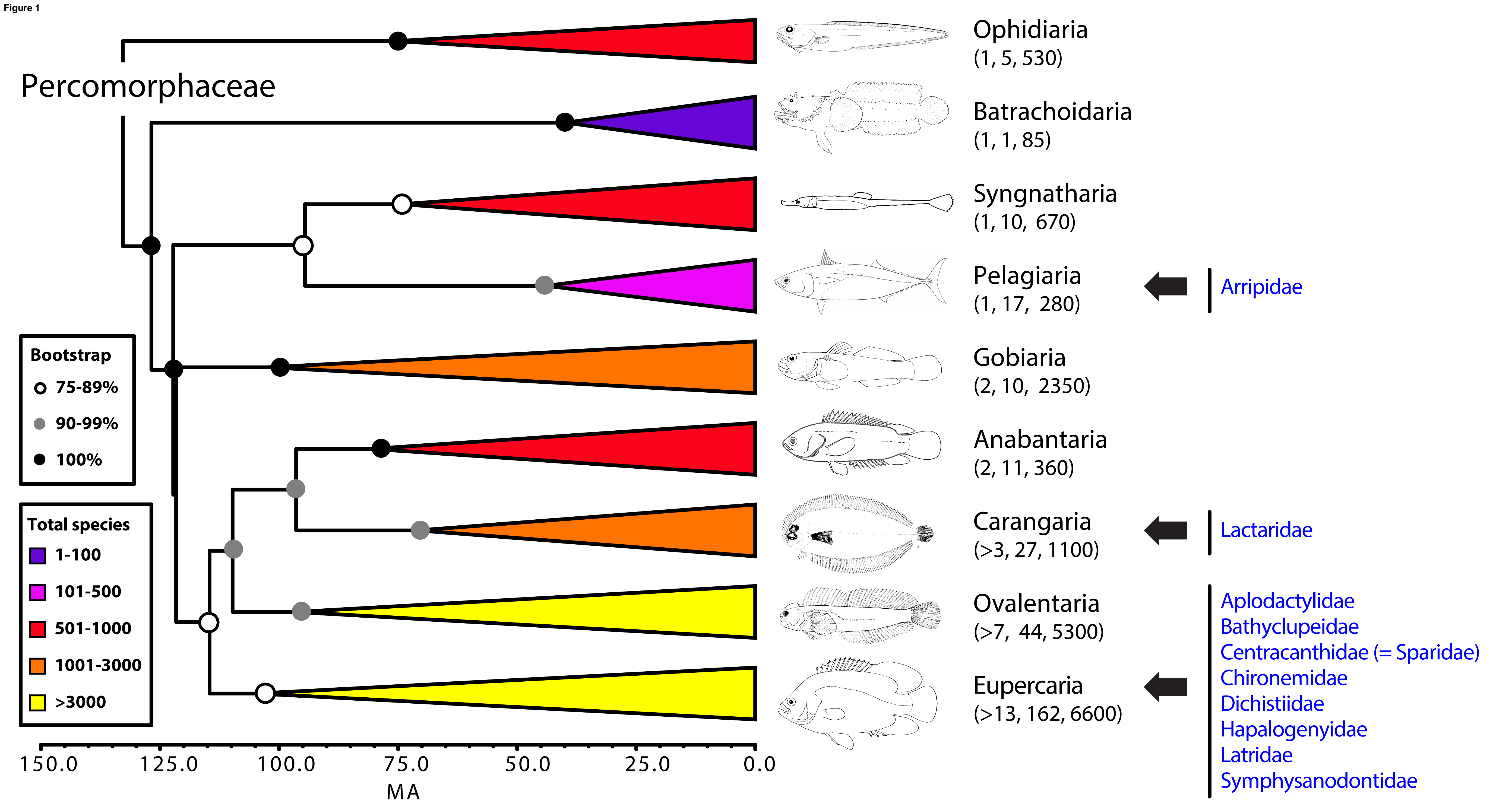




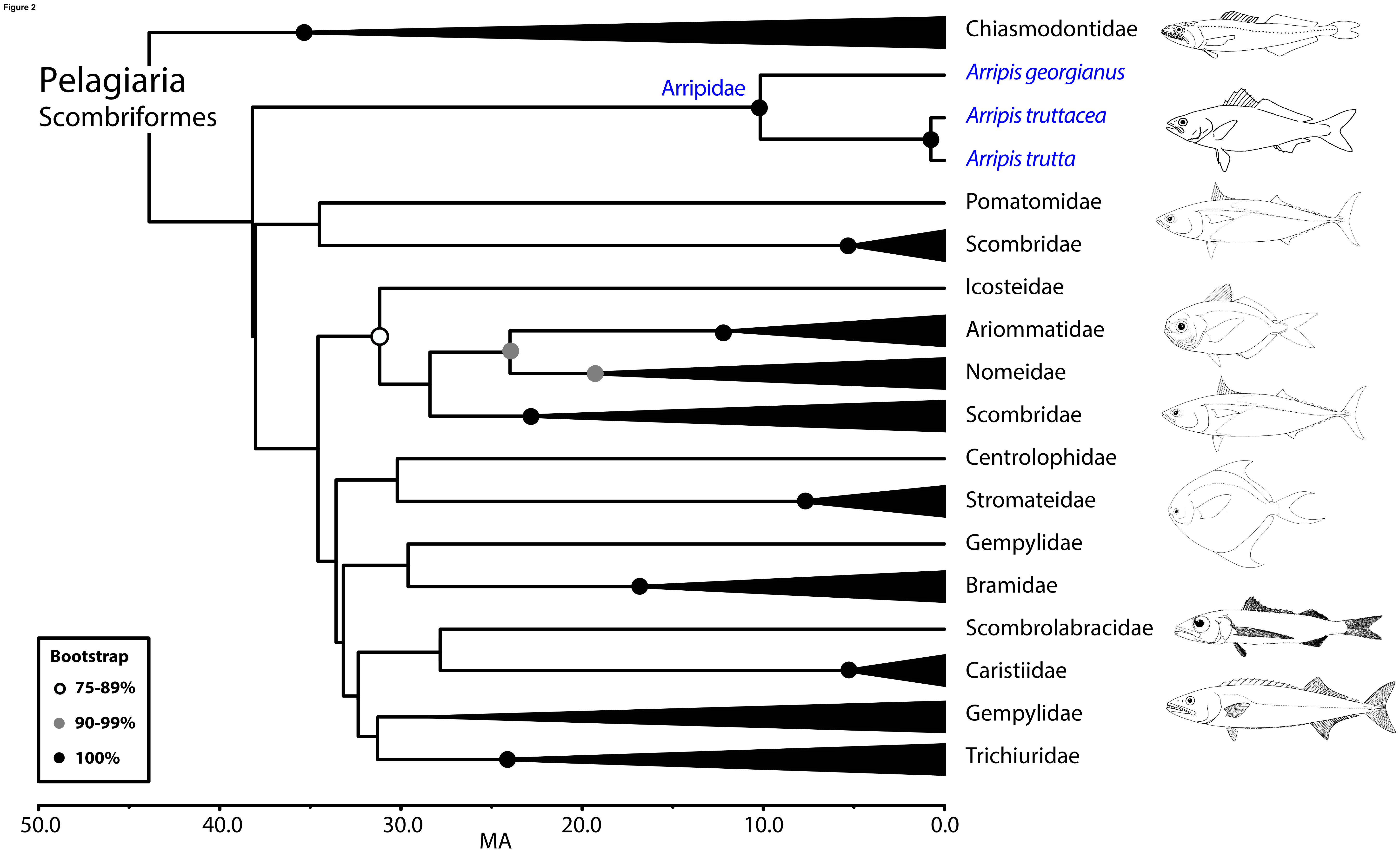




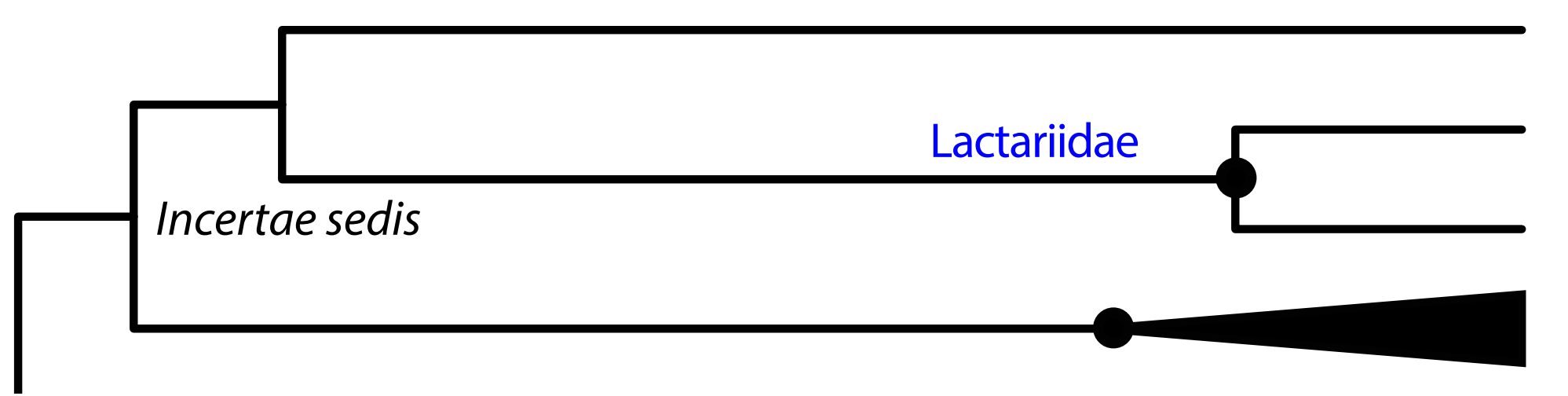

\section{Carangaria}
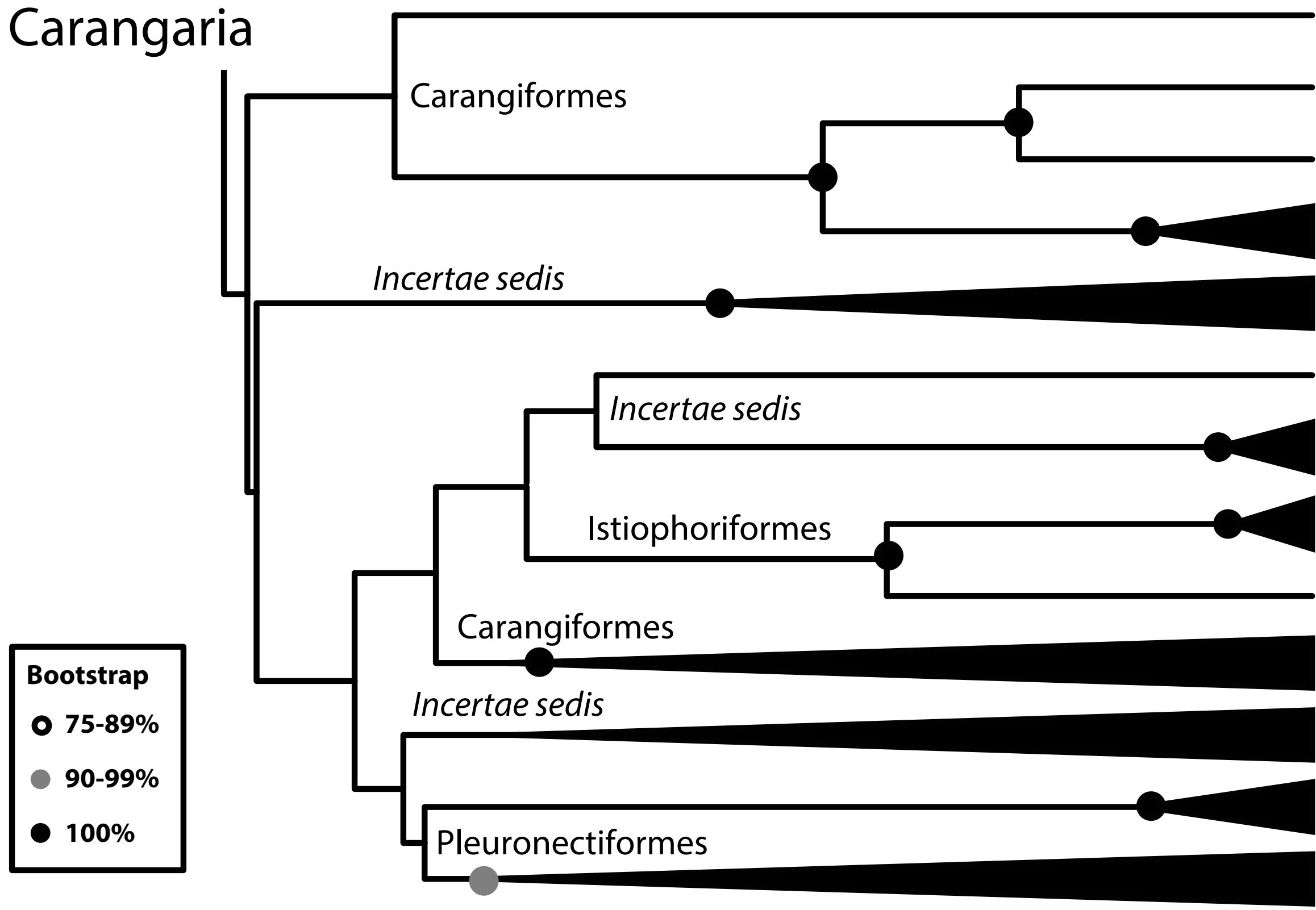

Nematistiidae

Coryphaenidae

Rachycentridae

Echeneidae

Sphyraenidae

Leptobramidae

Toxotidae

Istiophoridae

Xiphiidae

Carangidae

Centropomidae

Psettodoidei

Pleuronectoidei
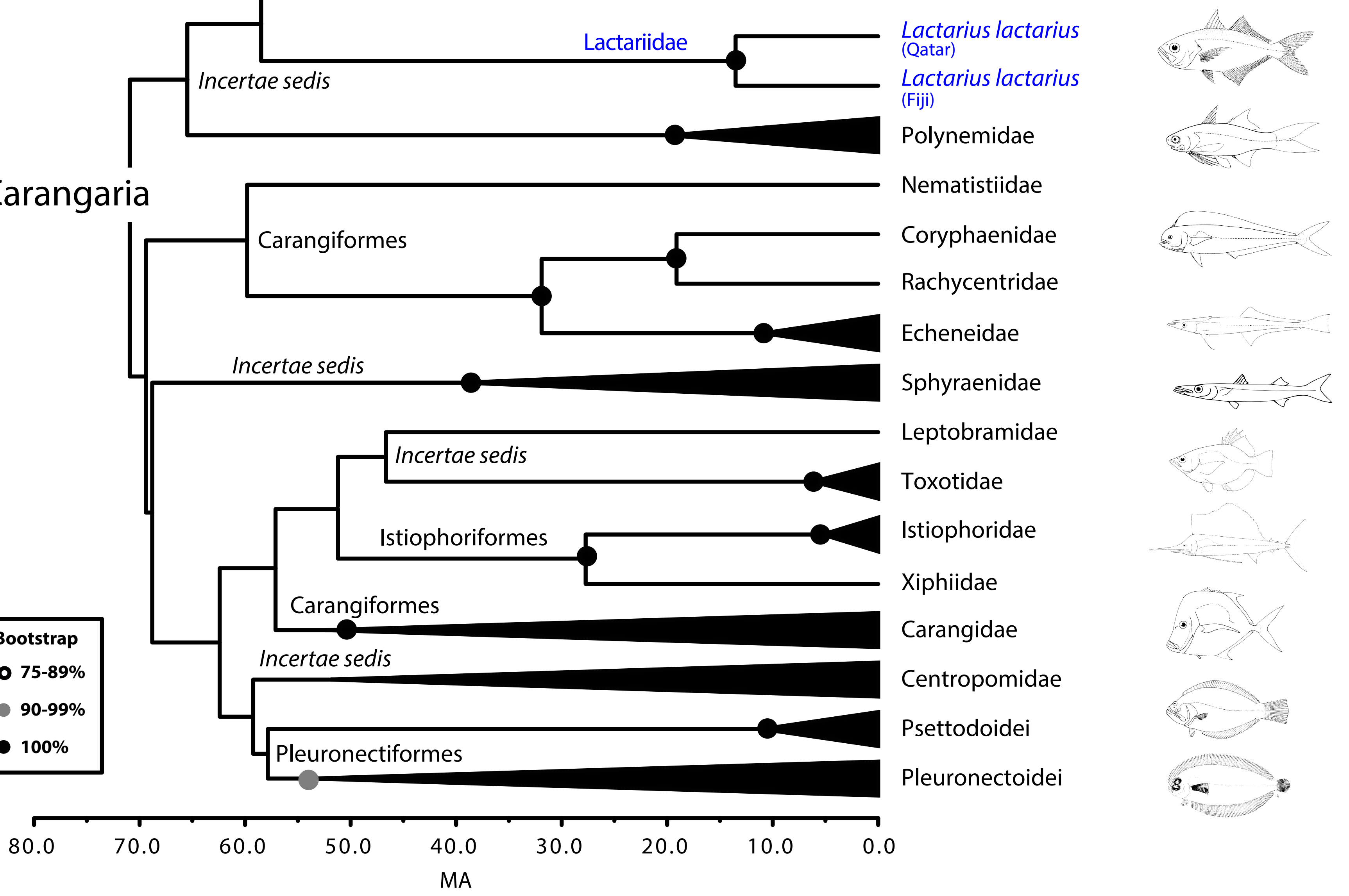

MA 


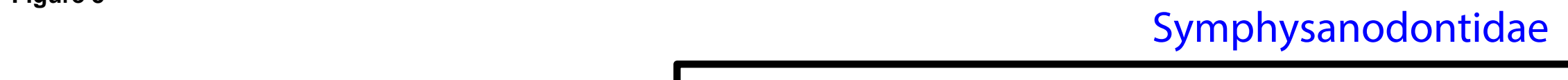

\section{Eupercaria} (in part) Pempheriformes

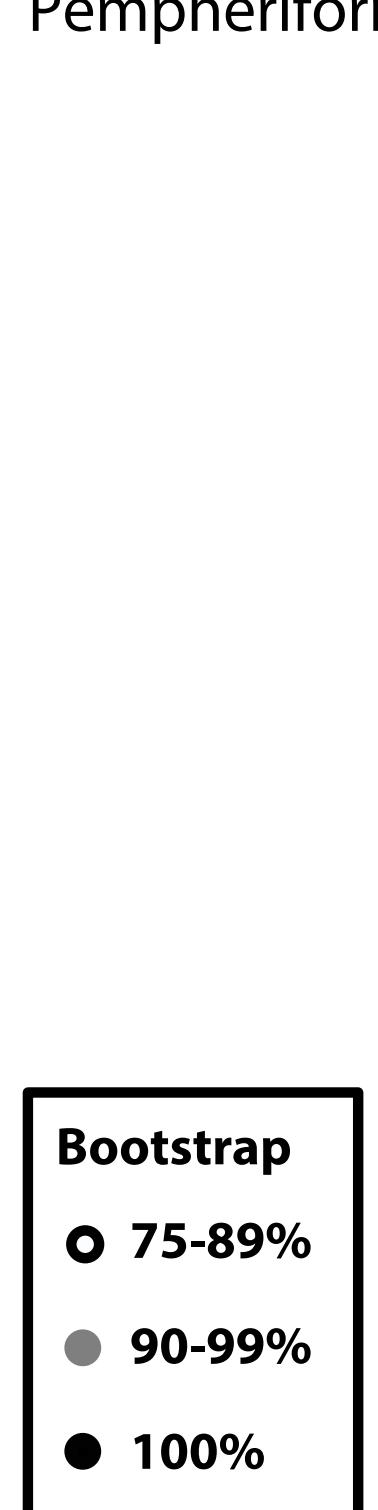

Symphysanodon typus

Epigonidae

Acropomatidae

Ostracoberycidae

Howellidae

Acropomatidae

Lateolabracidae

Champsodontidae

Percophidae

Creediidae

Glaucosomatidae

Pempheridae

Acropomatidae

Bathyclupeidae

Bathyclupea argentea

Polyprionidae

Banjosidae

Pentacerotidae
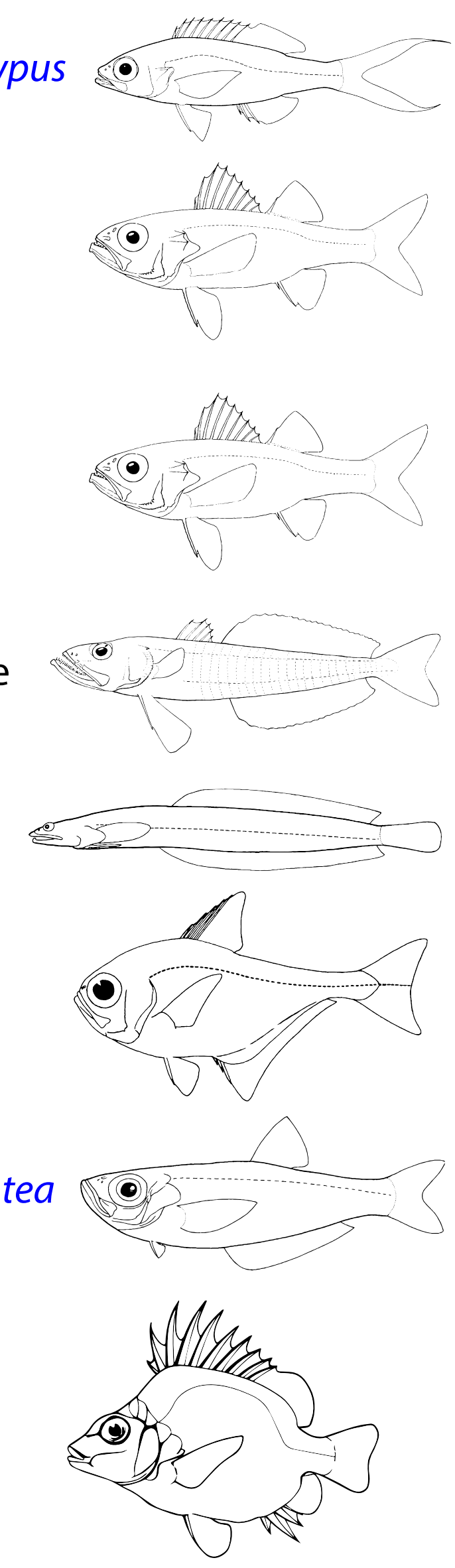


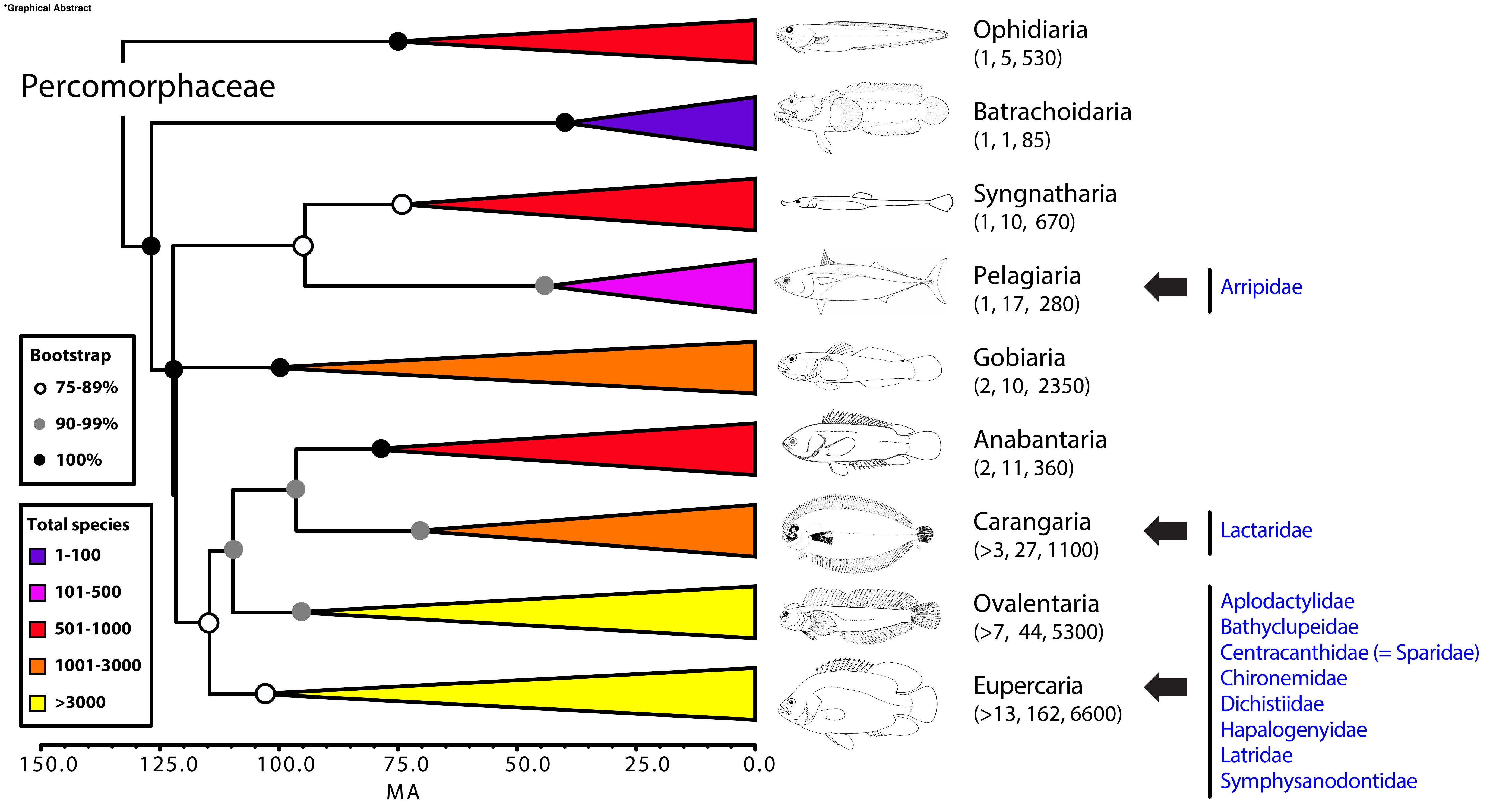

